\title{
STRATEGI PELIBATAN MAHASISWA DALAM PEMBELAJARAN DARING: STUDI KASUS PADA MATA KULIAH SEPAK TAKRAW
}

\section{STRATEGIES TO ENGAGE STUDENTS IN AN ONLINE COURSE: A CASE STUDY IN A SEPAK TAKRAW COURSE}

\section{Ketut Semarayasa*, Ni Luh Putu Spyanawati}

Pendidikan Jasmani, Kesehatan, dan Rekreasi, Universitas Pendidikan Ganesha,Indonesia

*Corresponding Author: I Ketut Semarayasa, ketut.semarayasa@undiksha.ac.id

Received: 2021-09-30 ; Revised: 202-10-12; Accepted: 2021-11-02

\begin{abstract}
Abstrak
Tujuan artikel ini adalah untuk menggambarkan strategi-strategi yang digunakan oleh dosen untuk melibatkan mahasiswa dalam pembelajaran daring pada mata kuliah sepak takraw. Rancangan penelitian yang digunakan adalah penelitian studi kasus. Partisipan penelitian ini adalah satu orang dosen sepak takraw. Metode pengambilan data dilakukan melalui metode observasi dan wawancara. Instrumen penelitian yang digunakan adalah lembar observasi dan pedoman wawancara. Analisis data dilakukan dengan mengikuti analisis data tematik. Hasil penelitian menunjukkan bahwa dosen sepak takraw menyediakan tiga jenis interaksi: interaksi mahasiswa dengan dosen, interaksi mahasiswa dengan mahasiswa, dan interaksi mahasiswa dengan materi pembelajaran. Ketiga jenis interaksi ini dilakukan untuk menciptakan situasi pembelajaran yang aktif, positif, dan menyenangkan. Dengan demikian, tujuan pembelajaran bisa tercapai dengan baik.
\end{abstract}

Kata Kunci: pelibatan mahasiswa, sepak takraw, pembelajaran daring.

\begin{abstract}
This paper aims at describing a lecturer's strategies to engage students in a sepak takraw online learning. The research design used in this research was case study. The research participant was a sepaktakraw lecturer. Data were collected by conducting observation and interview. The research instruments used were observation sheet and interview guide. Data were analyzed by following thematic analysis. The results showed that the lecturer provided three ways of engagement: interaction between students and lecturer, interaction between student and student (s), and interaction between student and learning materials. These interactions were implemented to create an active, positive, and enjoyful learning atmosphere. In so doing, the learning objectives can be achieved well.
\end{abstract}

Keywords: student engagement, sepak takraw, online learning

How To Cite: Semarayasa, I. K., Spyanawati, N.L.P. (2021). Strategi pelibatan mahasiswa dalam pembelajaran daring pada mata kuliah sepak takraw. Journal of Sport Education (JOPE), 4 (1), $40-54$. doi:http://dx.doi.org/10.31258/jope.4.1.40-54

Journal Of Sport Education (JOPE) is an open access article under the CC-BY-SA 4.0

\section{PENDAHULUAN}

Semenjak covid 19 merebak di Indonesia, pembelajaran di perguruan tinggi mengalami perubahan, dari yang semula dilakukan melalui tatap muka menjadi pembelajaran daring. Semenjak diberlakukannya pembelajaran daring, banyak mahasiswa yang merasa kurang termotivasi untuk belajar (Yunitasari \& Hanifah, 2020). Salah satu penyebab menurunnya motivasi mereka adalah kurangnya "kehadiran" dosen dan sedikitnya interaksi selama pembelajaran daring berlangsung. Sebagian dosen hanya menyediakan materi berupa 
PowerPoint atau buku-buku/artikel-artikel untuk dibaca dengan sedikit kesempatan untuk berdiskusi. Sebagian dosen lagi kerap memberikan tugas kepada mahasiswa tanpa memberikan feedback yang bisa dipahami oleh mahasiswa. Sangat sedikit juga kesempatan bagi mahasiswa untuk bisa bertemu dan berdiskusi secara daring melalui platform-platform yang digunakan oleh dosen.

Fenomena ini menyebabkan mahasiswa merasa sendiri, kesepian, dan frustasi. Mereka merindukan adanya sebuah "offline class atmosphere" yang menyediakan "ruang" bagi mereka untuk bisa berinteraksi baik dengan sesama teman maupun dengan dosen. Berdasarkan hasil pengamatan yang dilakukan pada kelas maya di Program Studi Pendidikan Jasmani, Rekreasi, dan Kesehatan di salah satu universitas negeri di Bali, Indonesia, terlihat bahwa selama pembelajaran daring mahasiswa memiliki keterbatasan dalam berinteraksi. Hal ini memunculkan perasaan bosan pada mahasiswa. Hal ini memunculkan perasaan bosan pada mahasiswa. Pernyataan ini juga diperkuat oleh hasil penelitian yang dilakukan oleh Pawicara dan Conilie (2020), dimana kejenuhan siswa dalam pembelajaran daring disebabkan oleh pelaksanaan perkuliahan daring yang monoton, materi/media yang kurang menarik, serta sedikitnya interaksi antara siswa dengan guru/dosen.

Pada pembelajaran daring, satu elemen penting yang harus ada adalah keterlibatan mahasiswa (Yang, 2011). Keterlibatan mahasiswa diartikan sebagai ketertarikan, keingintahuan, dan gairah yang ditunjukkan oleh mahasiswa dalam proses belajar mengajar (Mulia, 2020). Menurut Dixson (2010), terdapat empat aspek keterlibatan siswa: perilaku / keterampilan, emosional, partisipasi / interaksi, dan interaksi kognitif. Keempat komponen ini bersinergi satu dengan yang lainnya dalam mencapai tujuan pembelajarannya, dimana keterlibatan siswa telah dibuktikan mampu meningkatkan prestasi belajar siswa (Banna, Lin, Stewart, \& Fialkowski, 2015; Galikyan \& Admiraal, 2019).

Dalam pelibatan mahasiswa, dosen berperan utama dalam meningkatkan keterlibatan mahasiswa. Beberapa literatur menyatakan bahwa terdapat beberapa strategi yang bisa dilakukan oleh guru/dosen untuk meningkatkan keterlibatan siswa dalam pembelajaran daring. Yengin, Karahoca, Karahoca, dan Yucel, (2010) menyebutkan ada empat strategi yang bisa dilakukan untuk meningkatkan keterlibatan siswa: a) menggunakan pembelajaran aktif, b) memotivasi siswa, c) memberikan feedback, dan d) menggunakan platform yang sesuai. Senada dengan hal ini, Khan, Egbue, Palkie, dan Madden (2017) juga mengungkapkan bahwa ada empat cara yang bisa dilakukan untuk meningkatkan keterlibatan siswa: a) memudahkan akses materi pembelajaran, b) membuat komunitas belajar, c) menyediakan ruang diskusi, dan d) merancang teknik penilaian yang efektif.

Keterlibatan mahasiswa hendaknya dijadikan bagian yang utama pada pembelajaran bahkan dimasukkan pada aspek penilaian mahasiswa (Gunuc, 2014). Sun dan Chen (2016) juga menyatakan bahwa keterlibatan mahasiswa adalah jantung dari setiap pembelajaran daring, termasuk pada mata kuliah sepak takraw. Pada mata kuliah sepak takraw, dosen tidak hanya mengajarkan tentang teori sepak takraw tetapi juga keterampilan dasar dalam bermain sepak takraw. Hal ini disebabkan karena pada akhir perkuliahan, tujuan pembelajaran yang harus dicapai oleh mahasiswa adalah mampu mendemonstrasikan teknik-teknik dasar bermain sepak takraw seperti sepak sila, sepak mula, sepak kuda, sepak badek, sepak cungkil, memaha, mendada, menapak, heading, smash, dan blocking (Wahyudi, Budiman, \& Saepudin, 2018). Dengan demikian, dosen sepak takraw harus mampu merancang kegiatan yang mampu melibatkan siswa sehingga kelas daring akan lebih hidup. Dengan strategi pelibatan mahasiswa yang baik, motivasi belajar mahasiswa akan meningkat, dan hasil belajar pun bisa dicapai oleh mahasiswa dengan baik. Oleh karena itu, sangat penting untuk menciptakan ruang bagi mahasiswa untuk terlibat aktif dalam pembelajaran daring. Bahkan, Banna, Lin, Stewart, dan Fialkowski (2015) menekankan bahwa keterlibatan adalah solusi utama dari permasalahan yang dialami mahasiwa seperti perasaan terisolasi dan putus sekolah. 
Mengingat pentingnya pelibatan mahasiswa dalam pembelajaran, banyak peneliti yang meneliti keterlibatan siswa dalam pembelajaran seperti (Dahalan, Hassan,\& Atan, 2011 ; Martin \& Blogger, 2018; Mulia, 2010; Wong, 2013). Penelitian-penelitian mengkaji pelibatan dosen dari perspektif siswa/mahasiswa melalui pendekatan kuantitatif. Sedikit penelitian yang meneliti tentang pelibatan siswa dari perspektif guru/dosen melalui pendekatan kualitatif, terutama pada konteks pembelajaran sepak takraw. Untuk mengisi kesenjangan empiris dan metodologis ini, kami melakukan penelitian kualitatif yang bertujuan untuk meneliti bagaimana dosen sepak takraw melibatkan mahasiswa dalam pembelajaran daring yang diampunya. Dengan menggunakan pendekatan kualitatif dengan desain penelitian studi kasus, strategi pelibatan mahasiswa dalam pembelajaran daring pada kasus pembelajaran praktek sepak takraw dideskripsikan secara lebih detil dimana data otentik diperoleh langsung dari pengalaman partisipan selama melakukan pembelajaran daring pada konteks penelitian yang diteliti dan melalui pengamatan langsung yang dilakukan oleh peneliti. Dengan demikian, penelitian ini mampu mengekplorasi dan mendokumentasikan bagaimana dosen pendidikan jasmani rekreasi dan kesehatan khususnya sepak takraw melibatkan mahasiswa dalam pembelajaran daring dengan lebih detil dan rinci.

Wong (2013) juga melakukan penelitian survey tentang tingkat pelibatan siswa dalam pembelajaran daring dengan menggunakan platform WebCT. Penelitian dilakukan dengan menyebarkan kuesioner kepada seratus tujuh puluh dua orang responden. Kuesioner diberikan pada akhir semester, ketika perkuliahan telah selesai dilakukan. Hasil penelitian menunjukkan bahwa platform WebCT mampu memfasilitasi keterlibatan siswa selama pembelajaran daring dilakukan. Penelitian ini juga memberikan rekomendasi terkait fiturfitur apa saja yang bisa dimasukkan pada suatu platform pembelajaran daring agar bisa melibatkan siswa dengan efektif.

Penelitian ini penting untuk memberikan implikasi pada pelaksanaan pembelajaran daring. Melalui hasil penelitian ini, dosen-dosen yang mengajar pada bidang olahraga akan mendapatkan gambaran tentang strategi-strategi pelibatan mahasiswa yang bisa diterapkan dalam pembelajaran daring. Strategi-strategi pelibatan mahasiswa ini, selanjutnya bisa dijadikan acuan dalam menyelenggarakan pembelajaran daring dan diharapkan mampu meningkatkan motivasi dan hasil belajar mahasiswa. Di samping itu, penelitian ini juga akan mampu menambah literatur dan membantu peneliti lain dalam membangun strategi keterlibatan mahasiswa untuk pembelajaran online pada konteks pendidikan olahraga.

Untuk memenuhi kebutuhan ini, penelitian ini berusaha menjawab pertanyaan sebagai berikut: Bagaimanakah bentuk-bentuk strategi yang digunakan oleh dosen sepak takraw untuk melibatkan mahasiswa dalam pembelajaran daring? Dari pertanyan penelitian ini, tujuan penelitian ini adalah untuk mendeskripsikan bentuk-bentuk strategi pelibatan mahasiswa yang dilakukan oleh dosen sepak takraw dalam pembelajaran daring. Artikel ini akan mengeksplorasi bagaimana peran dosen dalam menyelenggarakan pembelajaran daring pada mata kuliah sepak takraw, terutama dari aspek pelibatan mahasiswa.

\section{METODE}

Untuk mencapai tujuan penelitian, kami menggunakan pendekatan penelitian kualitatif. Penelitian ini kami pilih karena melalui penelitian ini kami memiliki peluang untuk mengamati, mendengar, dan menganalisis data secara natural pada konteks yang sebenarnya. Seperti yang dikemukan oleh Creswell (2007), penelitian kualitatif berusaha memahami dan menafsirkan prilaku, pengalaman, dan interaksi orang yang terjadi secara alamiah pada konteks penelitian yang sedang diteliti. Dalam konteks penelitian ini, fenomena yang dikaji adalah strategi pelibatan mahasiswa pada pembelajaran daring sepak takraw. Dengan demikian, melalui pendekatan kualitatif, penelitian ini menggambarkan bagaimana strategi pelibatan mahasiswa ini dilakukan oleh partisipan. 
Dari beberapa jenis penelitian kualitatif, penelitian jenis studi kasus digunakan dalam penelitian ini. Menurut Creswell (2009), penelitian studi kasus mampu mengeksplorasi suatu masalah dengan menggunakan kasus sebagai ilustrasi yang khusus. Sesuai dengan yang dikemukakan oleh Yin (2018), kasus bisa mengacu pada suatu kegiatan yang berada pada suatu konteks tertentu. Mengacu pada definisi ini, kami mengeksplorasi isu pelaksanaan pembelajaran daring, dengan mengambil kegiatan pelibatan mahasiswa yang dilakukan oleh dosen sebagai kasus yang kami teliti. Melalui penelitian studi kasus ini, kami memberikan pemahaman yang bermakna dan konteksual dari strategi pelibatan mahasiswa yang dilakukan oleh dosen pada pembelajaran daring. Tujuan penelitian studi kasus kami ini sejalan dengan jenis penelitian instrumental case study yang dikemukan oleh Stake (1995, 2005), dimana melalui penelitian ini, kasus yang kami teliti memberikan wawasan tentang penggunaan strategi pelibatan mahasiswa yang dilakukan oleh dosen sepak takraw.

Penelitian ini dilakukan di salah satu program studi pendidikan jasmani dan rekreasi yang ada di universitas negeri di Bali, Indonesia. Pemilihan tempat penelitian ini didasari oleh beberapa pertimbangan. Satu, program studi ini memiliki kurikulum yang mengajarkan keterampilan dasar bermain sepak takraw untuk mahasiswanya. Selain memasukkan ke dalam kurikulum, sepak takraw juga dimasukkan pada kegiatan ekstra kurikuler yaitu bimbingan prestasi. Dua, program studi ini memiliki dosen pengampu mata kuliah sepak takraw yang memiliki keahlian dalam mendemonstrasikan teknik dasar bermain sepak takraw, dimana dosen pengampu mata kuliah ini merupakan mantan-mantan atlit sepak takraw tingkat nasional maupun internasional. Tiga, Program studi ini memiliki fasilitas penyelenggaraan pembelajaran daring yang melembaga melalui learning management system (LMS) institusi. Empat, kami memiliki akses yang mudah untuk mengambil data penelitian mengingat kami merupakan dosen yang juga mengajar di prodi ini. Mata kuliah sepak takraw dipilih karena pembelajaran sepak takraw merupakan mata kuliah keterampilan yang banyak melibatkan bentuk-bentuk interaksi baik dengan dosen maupun dengan sesama teman. Dengan demikian, kami bisa memotret strategi-strategi yang digunakan oleh dosen untuk melibatkan mahasiswa selama pembelajaran daring.

Pembelajaran sepak takraw dalam konteks penelitian ini dilaksanakan sepenuhnya melalui daring dengan menggunakan mode asinkronus (LMS institusi) dan asinkronus (Google Meet dan Zoom). Pada mode asinkronus, Bapak Satya melakukan pembelajaran daring dengan tahap a) meminta mahasiswa mempelajari materi secara mandiri atau berkelompok, b) meminta mahasiswa untuk memperdalam pemahaman mereka terkait dengan materi yang dipelajari melalui forum diskusi, dan c) melakukan penilaian sejauh mana mahasiswa sudah memahami materi yang dipelajari. Pada mode sinkronus, Bapak Satya melakukan review terkait materi yang dipelajari oleh mahasiswa dan memberikan komentar/feedback pada tugas-tugas yang dikerjakan oleh mahasiswa.

Kegiatan penelitian dilakukan pada saat semester ganjil tahun akademik 2020/2021. Kegiatan pembelajaran dilakukan selama empat belas pertemuan dari bulan Agustus sampai dengan bulan Nopember 2020. Kegiatan penelitian mengikuti jadwal pembelajaran yang dilakukan oleh dosen. Pada saat kegiatan penelitian berlangsung, pembelajaran dilakukan secara daring penuh, tidak ada pembelajaran tatap-muka (luring).

Sebelum mengambil data, kami melakukan hal-hal sebagai berikut. Pertama, meminta ijin kepada ketua program studi pendidikan jasmani, kesehatan, dan rekreasi. Proses permintaan ijin dilakukan secara langsung dimana salah satu tim peneliti berkomunikasi langsung menyampaikan tujuan dan manfaat penelitian ini. Pada tahapan ini kami menyerahkan surat ijin melakukan penelitian dari Lembaga Penelitian dan pengabdian kepada Masyarakat dari institusi kami. Kedua, setelah proses perijinan dipenuhi, kami diarahkan untuk menemui dosen pengampu mata kuliah untuk meminta kesediaan para pengampu mata kuliah ini terlibat dalam penelitian ini. Terdapat dua orang dosen yang 
mengampu mata kuliah ini: Bapak Yasa dan Bapak Satya (nama samaran). Dalam kesempatan ini, kami tidak hanya menyampaikan tujuan dan manfaat penelitian, tetapi juga teknis pengambilan data. Kami mendiskusikan hal-hal yang kami butuhkan dari mereka serta waktuwaktu yang nyaman bagi mereka untuk kami observasi/wawancara. Kami juga memastikan kerahasiaan identitas mereka. Hal ini dilakukan untuk memenuhi kode etik penelitian, dimana dalam penelitian kualitatif kode etik dalam pengambilan data dan pelaporan data penting untuk dilakukan (Miles, Huberman \& Saldana, 2014). Setelah berdiskusi, hanya Bapak Satya saja yang bersedia untuk terlibat dalam penelitian ini. Untuk memenuhi kode etik penelitian kualitatif, kami memohon kesediaan Bapak Satya untuk mengisi surat pernyataan kesediaan terlibat dalam penelitian.

Seperti yang disampaikan pada bagian akses penelitian, satu orang dosen pengampu mata kuliah teknik dasar bermain sepak takraw-Bapak Satya-terlibat dalam penelitian ini dan bersedia untuk menjadi partisipan penelitian. Bapak Satya merupakan dosen PNS yang mengampu mata kuliah sepak takraw. Beliau telah mengampu mata kuliah ini sejak beliau ditugaskan sebagai dosen di program studi ini, yaitu tahun 2007. Selain memiliki keterampilan mengajar yang baik, Bapak Satya juga merupakan mantan atlit sepak takraw. Sebelum pandemi covid-19, Bapak Satya melakukan kegiatan pembelajaran sepak takraw melalui pembelajaran tatap muka baik di kelas maupun di lapangan. Tetapi, semenjak covid19, Bapak Satya melakukan pembelajaran secara daring melalui moda sinkronus (Google Meet/Zoom) dan asinkronus (Learning Management System institusi).

Untuk mengumpulkan data, kami melakukan tiga teknik: observasi, wawancara, dan analisis konten. Masing-masing teknik dijabarkan sebagai berikut.

Observasi dilakukan dengan ikut serta mengamati kegiatan pembelajaran yang terjadi selama proses pembelajaran baik secara sinkronus maupun asinkronus. Observasi pada kegiatan pembelajaran sinkronus dilakukan dengan ikut bergabung pada kelas virtual baik melalui Google Meet maupun Zoom. Dosen pengampu mengirimkan link kepada kami untuk bisa bergabung di kelas online. Tujuan kami ikut bergabung di kelas daring adalah untuk bisa melihat, mendengar, dan merasakan secara langsung bagaimana Bapak Satya melakukan pelibatan mahasiswa di dalam kelas yang diampunya. Ini sejalan dengan apa yang dikemukakan oleh Stake (2010) bahwa dalam penelitian studi kasus, kegiatan observasi langsung tidak hanya bertujuan untuk dekat dengan partisipan tetapi lebih kepada merasakan dan mengalami langsung hal-hal yang diteliti.

Selain melakukan observasi secara langsung, kami juga meminta Bapak Satya untuk mengirimkan kepada kami link rekaman kegiatan pembelajaran yang dilakukannya. Hal ini kami lakukan untuk melengkapi keterbatasan kami dalam mencatat hal-hal yang terjadi pada saat kegiatan observasi langsung dilakukan. Dengan demikian, kami akan mendapat gambaran apa yang dilakukan oleh dosen untuk melibatkan mahasiswa di kelasnya serta bagaimana dosen melakukan pelibatan mahasiswa. Seperti yang dikemukakan oleh Silverman (2015) bahwa teknik observasi ini dapat memberi kesempatan kepada peneliti untuk melihat, mendengar, dan merekam apa yang terjadi pada konteks penelitian yang sedang diteliti.

Selama kegiatan observasi ini, kami berperan sebagai pengamat yang pasif. Kami mencatat hal-hal yang terjadi selama pembelajaran berlangsung pada instrumen protokol observasi. Adapun hal-hal yang kami amati adalah bagaimana kegiatan pembukaan pembelajaran dilakukan, bagaimana kegiatan inti pembelajaran dilakukan, bagaimana interaksi yang dilakukan, bagaimana kegiatan menutup pembelajaran dilakukan. Di samping aspek-aspek ini, kami juga mencatat bahasa, mimik wajah, dan gerak tubuh yang digunakan oleh Bapak Satya selama mengajar/berinteraksi di kelas maya. Kegiatan observasi dilakukan selama empat kali dengan rincian sebagai berikut. 
Journal Of Sport Education (JOPE), 4 (1) 2021 - 45

I Ketut Semarayasa*, Ni Luh Putu Spyanawati

Tabel 1. Jadwal observasi langsung di Google Meet/Zoom

\begin{tabular}{|c|c|c|c|c|}
\hline No & Tanggal & Waktu & Topik & Platform \\
\hline 1 & $\begin{array}{l}\text { Senin, } 24 \\
\text { Agustus } 2020\end{array}$ & 9.30-11.15 Wita & $\begin{array}{l}\text { Perkenalan dan } \\
\text { pemberian outline } \\
\text { kegiatan pembelajaran }\end{array}$ & Zoom \\
\hline 2 & $\begin{array}{l}\text { Senin, } 31 \\
\text { Agustus } 2020\end{array}$ & 9.30-11.15 Wita & $\begin{array}{l}\text { Review teknik dasar } \\
\text { sepak takraw }\end{array}$ & $\begin{array}{l}\text { Google } \\
\text { Meet }\end{array}$ \\
\hline 3 & $\begin{array}{l}\text { Senin, } 14 \\
\text { September } \\
2020\end{array}$ & 9.30-11.15 Wita & $\begin{array}{l}\text { Review teknik menahan } \\
\text { sepak takraw }\end{array}$ & $\begin{array}{l}\text { Google } \\
\text { Meet }\end{array}$ \\
\hline 4 & $\begin{array}{l}\text { Senin, } 28 \\
\text { September } \\
2020\end{array}$ & 9.30-11.15 Wita & $\begin{array}{l}\text { Review teknik serangan } \\
\text { sepak takraw }\end{array}$ & $\begin{array}{l}\text { Google } \\
\text { Meet }\end{array}$ \\
\hline
\end{tabular}

Selain melakukan pembelajaran daring dengan moda sinkronus, Bapak Satya juga melakukan pembelajaran daring melalui moda asinkronus dengan platform learning management system institusi. Dalam penelitian ini, kegiatan pembelajaran yang dilakukan melalui platform ini juga diteliti melalui analisis konten. Teknik analisis konten dilakukan untuk memperoleh gambaran tentang bentuk-bentuk strategi pelibatan mahasiswa yang digunakan oleh partisipan pada moda pembelajaran daring asinkronus melalui LMS. Pada tahapan ini, kami meminta ijin kepada Bapak Satya untuk mengakses pembelajaran sepaktakraw yang diselenggarakan melalui e-learning. Setelah kami masuk pada sistem ini, kami membaca dan mencermati jenis-jenis strategi pelibatan mahasiswa yang dilakukan oleh partisipan. Kecuali penggunaan gerakan tubuh, aspek-aspek yang kami amati sama dengan aspek-aspek yang kami amati pada saat pembelajaran dengan moda sinkronus. Terdapat sepuluh sesi pembelajaran yang ada di LMS. Kami mencermati kesepuluh sesi ini setelah kegiatan pembelajaran selesai dilakukan.

Teknik wawancara dilakukan untuk menggali persepsi dari partisipan tentang strategi-strategi yang dilakukan untuk melibatkan mahasiswa pada pembelajaran daring. Menurut Yin (2018), wawancara merupakan salah satu teknik yang penting dilakukan dalam penelitian kualitatif dengan desain penelitian studi kasus. Melalui wawancara, peneliti bisa menggali informasi lebih dalam tentang fenomena yang diteliti. Dalam konteks penelitian ini, wawancara dilakukan melalui telepon. Wawancara dilakukan sesaat setelah kegiatan observasi dilakukan. Dalam sesi wawancara ini, kami juga mengkonfirmasi hal-hal yang kami temukan pada teknik observasi. Wawancara dilakukan dengan teknik percakapan kasual untuk menghindari ketegangan partisipan. Wawancara di akhir kegiatan observasi berlangsung selama 15 sampai dengan 20 menit. Atas ijin dari Bapak Satya, kegiatan wawancara kami rekam melalui handphone yang kami gunakan. Dengan demikian, partisipan bisa lebih bebas untuk mengekpresikan pendapat dan pengalamannya terkait dengan upaya-upaya yang dilakukan untuk melibatkan mahasiswa pada pembelajaran daring. Selain empat kegiatan wawancara informal yang kami lakukan, kami juga melakukan wawancara formal melalui zoom. Kegiatan wawancara formal berlangsung selama 30 menit. Pada sesi wawancara ini kami menanyakan 1) pendapat Bapak Satya tentang pelibatan mahasiswa pada pembelajaran daring, 2) peran Bapak Satya selama melakukan pembelajaran daring, dan 3) strategi-strategi yang digunakan untuk melibatkan mahasiswa. Wawancara formal dilakukan setelah sesi pembelajaran selesai dilakukan yakni bulan Nopember 2020.

Analisis data dilakukan dengan mengadopsi tahapan analisis data tematik yang dikemukakan oleh Braun dan Clarke (2006). Analisis ini terdiri dari enam tahapan yaitu sebagai berikut. Satu, pembiasaan dengan data. Pada tahap ini, kami membaca transkrip 
wawancara dan transkrip percakapan dosen dengan mahasiswa selama pembelajaran berlangsung. Kami juga menonton kembali rekaman pembelajaran. Dua, menyusun kode awal. Pada tahap ini, kami memberi label atau kode pada data. Berbeda dengan teknik pengkodean yang dilakukan oleh Byrne (2021), dalam penelitian ini kami melakukan pengkodean secara manual, dimana transkrip wawancara dan kegiatan pembelajaran kami cetak. Setelah dietak, kami lalu mengkode dengan memberikan highlight menggunakan stabilo (pulpen berwarna). Kami menentukan kode baik secara deksriptif maupun interpretif. Pemberian highlight warna diberikan pada segmen yang ada di transkrip. Pengkodean pada data video dilakukan dengan melakukan tangkapan layar pada bagian yang mengandung data penelitian dan memberikan keterangan berupa deskripsi data. Tiga, Mencari tema. Pada tahap ini, kami mereview kode yang sudah diidentifikasi lalu memastikan kembali bahwa kode-kode tersebut memiliki makna yang sama. Pada tahapan ini, sesuai dengan yang dikemukan oleh Braun and Clark (2019), kami tidak mengambil tema langsung dari data, tetapi kami mengkonstruk tema melalui interpretasi. Empat, mereview tema. Pada tahap ini, kami membaca ulang tema-tema yang sudah diidentifikasi. Kami mencek bahwa tema-tema tersebut sudah sesuai dengan tujuan penelitian. Lima, mendefinisi dan memberi nama tema. Pada tahapan ini, kami mulai menamai masing-masing tema yang ditemukan. Enam, menuliskan laporan. Pada tahap ini, kami memaparkan temuan melalui laporan tertulis.

\section{HASIL}

Berdasarkan hasil observasi, analisis konten LMS, dan wawancara, Bapak Satya melakukan strategi pelibatan mahasiswa melalui penyediaan tiga jenis interaksi: interaksi mahasiswa dengan dosen, interaksi mahasiswa dengan mahasiswa, dan interaksi mahasiswa dengan materi pembelajaran. Masing-masing dijabarkan sebagai berikut.

Interaksi mahasiswa dengan dosen terjadi pada saat Bapak Satya mengajar di kelas daring baik melalui moda sinkronus maupun moda asinkronus. Adapun bentuk-bentuk interaksi yang dilakukan adalah sebagai berikut. Satu, menyapa mahasiswa di awal kegiatan pembelajaran. Melalui observasi, kami mengamati bahwa Bapak Satya memulai perkuliahan dengan menanyakan kabar dan keadaan mahasiswa. Beliau menyapa dengan hangat dan ramah disertai senyum kepada semua mahasiswa. Beliau mengabsen mahasiswa dan memastikan semua mahasiswa dalam keadaan baik dan siap untuk mengikuti perkuliahan daring. Dari hasil wawancara, Bapak Satya kembali menegaskan bahwa kegiatan menyapa mahasiswa sebelum memulai perkuliahan penting untuk dilakukan. Berikut petikan wawancara kami dengan beliau. Bagi saya, menyapa mahasiswa sebelum memulai pembelajaran penting untuk dilakukan, apalagi di masa yang seperti ini ya.. Dengan mengawali kegiatan melalui sapaan, kita sebenarnya sudah membuka ruang untuk berinteraksi. Mahasiswa tidak merasa tegang dan merasa diperhatikan.

Selain melalui moda sinkronus, kegiatan menyapa mahasiswa juga dilakukan pada LMS, seperti yang dapat dilihat pada Gambar 1 berikut.

Selamat siang adik-adik. Semoga semuanya dalam keadaan sehat dan berbahagia. Pada siang ini materi yang kita bahas adalah tentang sejarah permainan sepak takraw. Silakan adik-adik untuk membaca buku atau sumber lainnya. Setelah itu silakan berdikusi dan jawabalah pertanyaan -pertanyaan pada forum diskusi. Terimakasih kasih dan tetap semangat...

Gambar 1. Contoh kegiatan menyapa mahasiswa di LMS

Dari Gambar 1 Bapak Satya mengawali kegiatan pembelajaran dengan mendoakan mahasiswa agar mereka semua dalam keadaan sehat dan berbahagia. Kegiatan kedua yang dilakukan adalah, memberikan semangat dan motivasi kepada mahasiswa. Hal ini beliau lakukan untuk memberi kesan kehadiran bagi mahasiswa sehingga mahasiswa tidak merasa sendiri dalam mengerjakan tugas. Di samping memberikan motivasi melalui LMS, Bapak Satya 
juga memberikan motivasi kepada mahasiswa pada saat pembelajaran dilakukan secara sinkronus. Menurut Bapak Satya, pemberian motivasi ini dilakukan untuk menyemangati mahasiswa mengikuti perkuliahan daring. Seperti yang beliau tuturkan berikut ini: Motivasi internal penting untuk diberikan kepada mahasiswa agar mahasiswa tidak putus asa dan terus semangat selama mengikuti perkuliahan daring. Di masa ini, beberapa mahasiswa menghubungi saya, mereka bilang ingin cuti bahkan berhenti saja. Ada yang bermasalah secara finansial, ada juga karena stres belum terbiasa dengan pembelajaran daring. Makanya, penting untuk memompa semangat mereka untuk terus lanjut kuliah (Bapak Satya, wawancara, 24 Agustus 2020).

Menyadari bahwa mahasiswa merasakan kejenuhan dan kecenderungan memiliki permasalahan dalam mengikuti pembelajaran daring, Bapak Satya menyediakan ruang diskusi kepada mahasiswa untuk menyampaikan permasalahan yang dihadapi oleh mahasiswa. Pada saat pembelajaran melalui moda sinkronus, beliau menyampaikan sebagai berikut.: Adik-adik, jika adik-adik memiliki permasalahan atau kebingungan dalam pengerjaan tugas, jangan sungkan untuk menghubungi saya. Silakan hubungi saya di nomor yang sudah saya bagikan kepada korti.

Melalui wawancara beliau menegaskan lagi bahwa beliau mengijinkan mahasiswa untuk melakukan konsultasi, seperti yang dapat dilihat pada petikan wawancara berikut: Saya membolehkan mahasiswa untuk diskusi, konsultasi atau bertemu online dengan saya. Mereka bisa menelpon, mengirim pesan, atau bahkan melakukan video call. Asal disepakati waktunya. Mahasiswa biasanya menanyakan kesediaan saya sehari sebelumnya (Bapak Satya, wawancara, 24 Agustus 2020). Beliau selanjutnya menambahkan: Saya paham kondisi mahasiswa, pak. Kalau mereka dibiarkan sendiri, tentu mereka bingung lah. Walaupun mereka sudah mahasiswa, bukan berarti mereka bisa mengerjakan segalanya dengan mandiri. Mereka tentu butuh kita untuk mendampingi. Jadi, saya berusaha mendampingi mereka semampu saya. Kalau ngga gitu, bisa stress mereka pak (Bapak Satya, wawancara, 31 Agustus 2020).

Dari petikan wawancara di atas, dapat dilihat bahwa Bapak Satya menyediakan waktu khusus untuk mendampingi atau membimbing mahasiswa. Hal ini dilakukan karena beliau memahami bahwa mahasiswa membutuhkan arahan dan bimbingan, terutama terkait mata kuliah yang diajarkan. Dengan menyediakan waktu untuk diskusi secara daring, beliau berusaha memberikan kehadiran yang utuh kepada mahasiswa sehingga mahasiswa tidak merasa sendiri dan terisolasi. Pada kesempatan ini, Bapak Satya juga membuka ruang untuk mendiskusikan permasalahan yang dihadapi oleh mahasiswa. Dengan demikian, ketegangan dan frustasi yang dirasakan oleh mahasiswa bisa berkurang. Lambat laun, mahasiswa bisa mengerjakan tugas ataupun tagihan pembelajaran daring dengan baik.

Strategi ketiga yang dilakukan dalam penyediaan interaksi dengan dosen adalah pemberian feedback. Kegiatan pemberian feedback dilakukan pada moda asinkronus dan sinkronus. Pada pembelajaran ini, Bapak Satya memberikan tugas kepada mahasiswa untuk mempraktekkan passing sepak sila. Mahasiswa diminta untuk membuat video, kemudian menguploadnya ke LMS. Setelah mahasiswa mengupload, Bapak Satya memberikan penguatan secara personal terkait praktik yang sudah dilakukan oleh mahasiswa, seperti yang terlihat pada Gambar 2.

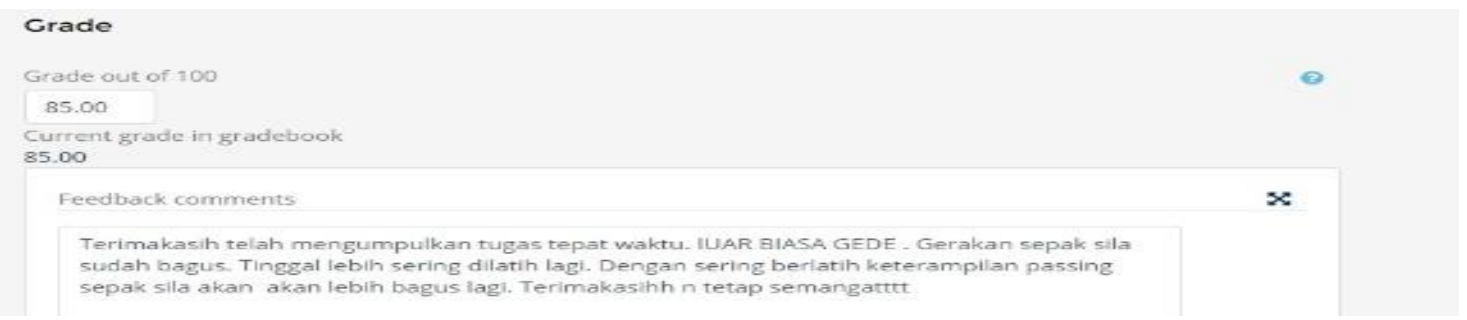

Gambar 2. Contoh pemberian feedback

Copyright (c) The Author (s) 2021

ISSN 2654-4474 (Print), ISSN 2654-9069 (Online) 
Pemberian feedback tidak hanya dilakukan dilakukan di LMS, tetapi juga dilakukan secara langsung melalui platform Google Meet. Seperti kegiatan pembelajaran yang kami amati di Google Meet, Bapak Satya mengajak mahasiswa bersama-sama mengamati gerakan, lalu menunjukkan bagian-bagian yang perlu diperbaiki. Beliau juga menyediakan contoh langsung maupun melalui video model. Hal ini dilakukan agar mahasiswa benar-benar memahami dan mampu mempraktekkan teknik passing sepak sila dengan baik. Pada sesi ini, Bapak Satya menyediakan ruang diskusi kepada mahasiswa dan membuka interaksi langsung dengan mahasiswa. Dengan pemberian koreksi/feedback, mahasiswa merasa dihargai. Berdasarkan penuturan Bapak Satya: Mahasiswa senang jika saya koreksi. Katanya, mereka ngga sia-sia buat tugas. Dengan memberikan koreksi, mereka merasa bahwa dosen ada bersama mereka. Mereka bisa belajar juga melalui koreksi yang kita berikan (Bapak Satya, wawancara, 14 September 2020).

Untuk menyediakan ruang interaksi antara mahasiswa dengan mahasiswa, Bapak Satya melakukan hal-hal sebagai berikut. Satu, mengimplementasikan pembelajaran berbasis proyek. Untuk membangun interaksi antar mahasiswa, Bapak Satya menggunakan pembelajaran kelompok dengan metode pembelajaran berbasis proyek. Pembelajaran dilakukan dengan meminta mahasiswa untuk bekerja secara berkelompok dalam bentuk presentasi dan membuat video praktek jenis keterampilan sepak takraw. Adapun rincian kegiatannya adalah sebagai berikut. Satu, Bapak Satya membagi mahasiswa menjadi tujuh kelompok, masing-masing kelompok terdiri dari empat orang mahasiswa. Dua, tiap-tiap kelompok diberi tugas untuk mempelajari teknik dasar dalam bermain sepak takraw. Tiga, tiap kelompok mempresentasikan hasil pemahaman mereka melalui kelas online di Google Meet. Empat, tiap kelompok mendemonstrasikan keterampilan teknik dasar bermain sepak takraw melalui video lalu mengunggahnya ke YouTube.

Menurut pengakuan beliau: Selama kuliah daring, saya minta mahasiswa untuk lebih banyak melakukan tugas proyek dalam kelompok. Saya bagikan topik untuk dipelajari lalu mereka presentasi di Google Meet. Tidak hanya itu, karena mata kuliah ini menekankan pada praktek, saya juga meminta mereka untuk membuat video untuk diupload di Youtube (Bapak Satya, wawancara, 14 September 2020). Beliau juga menambahkan: Kalau buat tugas sendiri di masa seperti sekarang kan cukup berat ya, jadi saya minta mereka mengerjakan tugas berkelompok saja. Mereka bisa diskusi, saling tanya, dan tetap berinteraksi satu sama lain dengan tetap melaksanakan prokes yang ketat (Bapak Satya, wawancara, 14 September 2020).

Dari petikan wawancara di atas, dapat dilihat bahwa penggunaan tugas kelompok dengan metode pembelajaran proyek yang dilakukan oleh Bapak Satya tidak hanya bertujuan untuk menjembatani ketercapaian tujuan pembelajaran tetapi juga sebuah upaya yang dilakukan untuk memberikan ruang kepada mahasiswa untuk bisa berinteraksi dengan mahasiswa lainnya.

Strategi kedua yang digunakan yaitu meminta mahasiswa melakukan penilaian teman sejawat. Dalam penerapan penugasan kelompok, Bapak Satya juga menugaskan mahasiswa untuk melakukan penilaian teman sejawat. Adapun prosedurnya adalah sebagai berikut. Satu, Bapak Satya meminta mahasiswa untuk membuat video praktek teknik dasar sepak takraw. Dua, Bapak Satya memberikan dan menjelaskan rubrik tentang acuan teknik sepak takraw yang baik. Tiga, Bapak Satya meminta mahasiswa untuk mengupload video ke YouTube. Empat, Bapak Satya membagi mahasiswa ke dalam beberapa kelompok dan menugaskan mahasiswa untuk menilai praktik teman mereka berdasarkan rubrik penilaian yang diberikan. Lima, tiap mahasiswa melaporkan hasil analisis dan penilaian mereka melalui Google Meet. Berikut adalah contoh video praktik yang dikerjakan oleh mahasiswa. Video lengkap tersedia di https://youtu.be/zRSSVUoBfgM.

Melalui percakapan pada sesi wawancara, Bapak Satya menuturkan: Saya meminta 
mahasiswa untuk menilai temannya. Jadi, mahasiswa tidak asal kumpul tugas proyek, lalu selesai. Ngga. Setelah dikumpul, saya minta mereka saling tukar video, lalu mengamati video teman dan memberi penilaian(Bapak Satya, wawancara, 28 September 2020). Beliau selanjutnya menambahkan: Saya ingin dengan melihat video temannya, mahasiswa bisa tahu apa kelebihan dan kelemahan mereka. Jadi, mereka bisa meningkatkan keterampilan teknik dasar mereka. Istilahnya, kalau lihat temannya lebih bagus, mereka bisa jengah dan memompa motivasi mereka untuk lebih baik (Bapak Satya, wawancara, Oktober 2020).

Dari petikan wawancara di atas, dapat dilihat bahwa pengalaman belajar yang dirancang oleh Bapak Satya memberikan ruang kepada mahasiswa untuk melakukan refleksi sejauh mana mahasiswa mampu mempraktekkan keterampilan dasar sepak takraw. Mereka mengamati praktek yang dilakukan oleh temannya, melihat kelebihan dan kekurangannya, lalu mengkomunikasikan hasil penilainnya dalam bentuk laporan.

Upaya lain yang dilakukan oleh Bapak Satya untuk membuat mahasiswa terlibat aktif dalam pembelajaran daring adalah dengan mendesain pembelajaran yang menarik dan mudah diakses oleh mahasiswa. Pembelajaran dirancang dengan menggunakan LMS elearning universitas dengan menyediakan materi dan sumber belajar yang bervariasi, seperti PowerPoint, buku, artikel, maupun video. Materi-materi tersebut mudah diakses oleh mahasiswa baik melalui laptop maupun handphone mereka. Dalam pembuatan PowerPoint dan materi, Bapak Satya menggunakan aplikasi Canva dengan desain-desain visual yang menarik. Hal ini dilakukan untuk menciptakan tampilan materi yang menarik untuk mahasiswa. Bapak Satya juga menggunakan video model sepak takraw yang menarik seperti yang terlihat pada Gambar 4 berikut. Video pembelajaran merupakan video pembelajaran yang dibuat oleh Bapak Satya dan tim, dimana bisa diakses pada https://www.youtube.com/watch?v=fhpa7F9DkK4. Video ini dimasukkan pada LMS yang digunakan oleh Bapak Satya dalam melaksanakan pembelajaran daring.

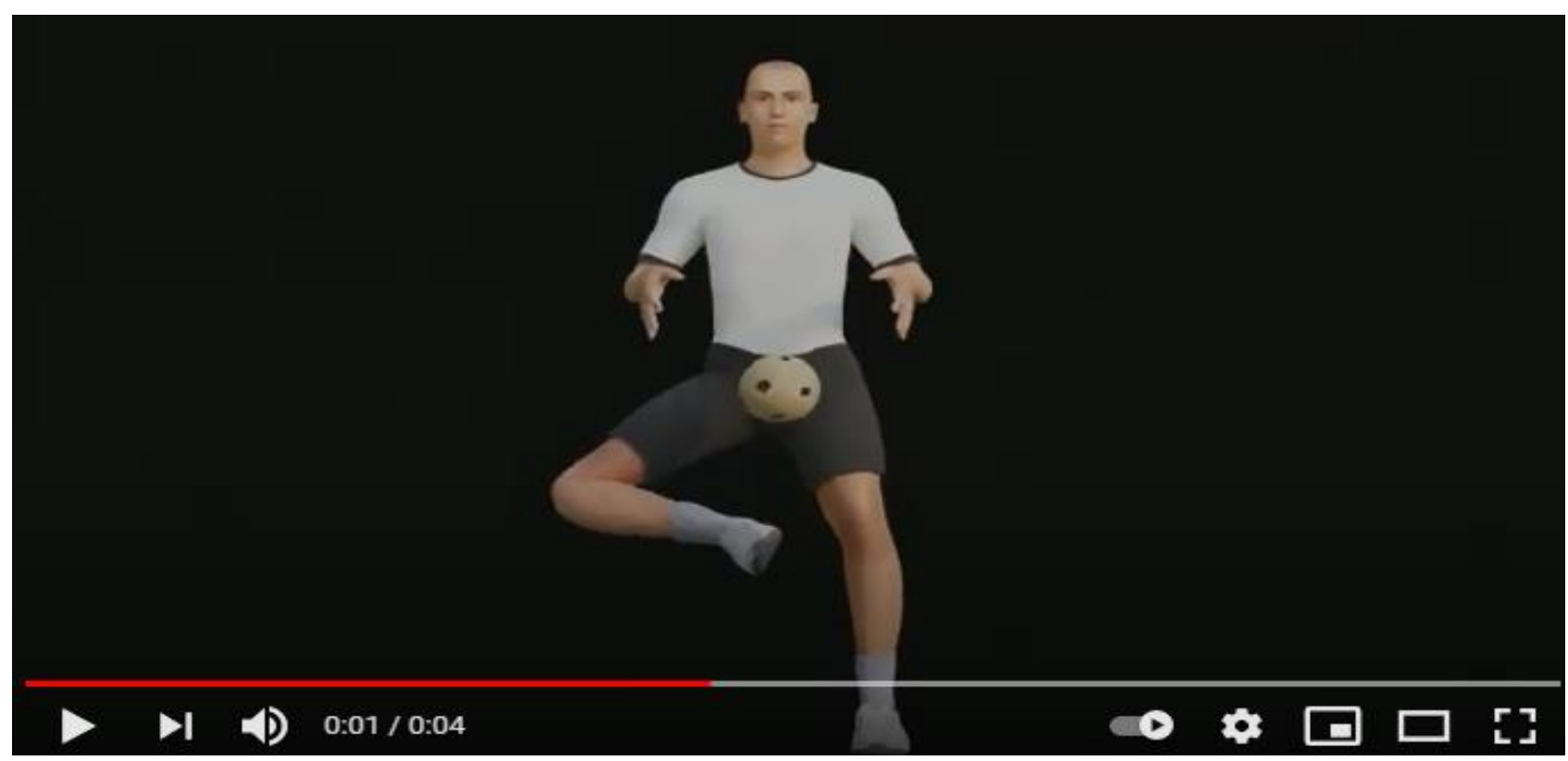

Gambar 3. Contoh video pembelajaran sepaktakraw yang dimasukkan pada LMS

\section{PEMBAHASAN}

Berdasarkan hasil penelitian dapat dilihat bahwa Bapak Satya melibatkan mahasiswa dalam pembelajaran daring melalui tiga jenis interaksi: interaksi mahasiswa dengan dosen, interaksi mahasiswa dengan mahasiswa dan interaksi mahasiswa dengan materi pembelajaran. Menurut Avianty dan Anantyarta (2020), interaksi antara mahasiswa dan dosen penting untuk dibangun selama pembelajaran daring. Bahkan, Martin dan Bolliger 
(2018) dalam penelitiannya menemukan bahwa dari tiga jenis interaksi, mahasiswa lebih membutuhkan interaksi mahasiswa dengan dosen. Hubungan yang terjalin antara dosen dan mahasiswa mampu menciptakan atmosfir pembelajaran yang positif, dimana mahasiswa merasa aman dan nyaman untuk mengikuti pembelajaran (Lee \& Martin, 2017). Dengan demikian, mahasiswa menjadi lebih bersemangat dan antusias untuk mengikuti proses pembelajaran (Reyes, Brackett, \& Rivers, 2012). Dalam penelitian ini, strategi-strategi yang dilakukan oleh Bapak Satya untuk berinteraksi dengan mahasiswa yaitu menggunakan fiturfitur sinkronus dan asikronus untuk menyelenggarakan pembelajaran, memberikan waktu dan ruang kepada mahasiswa untuk berdiskusi, menyapa mahasiswa melalui fitur sinkronus dan asinkronus, dan menyelipkan pesan-pesan motivasi kepada mahasiswa. Dengan strategistrategi ini, Bapak Satya berusaha untuk hadir di tengah-tengah mahasiswa selama pembelajaran daring.

Menurut Galikyan dan Admiraal (2019), kehadiran dosen sangat dibutuhkan oleh mahasiswa, terlebih lagi pada saat pembelajaran daring. Pada masa ini, mahasiswa membutuhkan pendampingan dan pembimbingan yang lebih intens dibandingkan pada saat pembelajaran offline di kelas. Hal ini terjadi karena pada masa ini mahasiswa cenderung memiliki permasalahan yang lebih kompleks. Beberapa mahasiswa masih belum terbiasa untuk melakukan pola pembelajaran daring. Beberapa mahasiswa lain masih bergelut dengan keterbatasan ekonomi dan geografis untuk bisa mengikuti pembelajaran daring dengan baik. Keterbatasan-keterbatasan ini cenderung membuat mereka mudah stress dan frustasi. Bahkan, beberapa dari kehilangan motivasi untuk belajar. Dengan penyediaan fitur-fitur pembelajaran daring yang bervariasi dan pemberian pesan-pesan motivasi oleh dosen, diharapkan mahasiswa bisa membangun semangat dan motivasinya untuk mengikuti pembelajaran. Selain itu, pemberian feedback dari dosen saat pembelajaran daring juga dipandang sebagai salah satu bentuk strategi untuk meningkatkan rasa percaya diri mahasiswa (Yengin, Karahoca, Karahoca, Yucel, 2010). Dengan melihat atau mendengar feedback yang diberikan oleh dosen, mahasiswa bisa menilai sejauh mana mereka bisa menunjukkan pemahaman mereka terhadap materi pembelajaran.

Selain melakukan upaya-upaya untuk memberikan kesempatan kepada mahasiswa untuk berinteraksi dengan dosen, Bapak Satya juga menyediakan ruang bagi mahasiswa untuk berinteraksi dengan mahasiswa lainnya. Hal ini dilakukan dengan merancang pembelajaran berbasis tugas kelompok dan meminta mahasiswa melakukan penilaian teman sejawat. Selama pembelajaran daring, mahasiswa cenderung merasa terisolasi, karena mereka berjauhan secara fisik. Untuk membuat mereka terkoneksi kembali, dosen perlu untuk merancang pembelajaran yang memaksa mereka untuk berkolaborasi dan berpartisipasi aktif dalam pembelajaran. Salah satu upaya yang dilakukan adalah dengan menggunakan pembelajaran berbasis proyek.

Secara teoritis, pembelajaran berbasis proyek yang memusatkan pembelajaran pada siswa, selain bertujuan untuk meningkatkan pembelajaran aktif dan kreatif, juga bertujuan untuk mengasah keterampilan bekerjasama dan berkolaborasi siswa (Mali, 2016). Dengan kerjasama dan kolaborasi yang baik, siswa mampu untuk menyelesaikan proyek yang ditugaskan. Hal ini telah dibuktikan oleh beberapa penelitian, misalnya, Al Rasyid dan Khoirunnisa (2021) dan Triana, Anggraito, dan Ridlo (2020). Mereka menemukan bahwa pembelajaran berbasis proyek terbukti mampu untuk meningkatkan keterampilan kolaboratif siswa. Pada konteks pembelajaran daring, kebutuhan akan mengimplementasikan pembelajaran berbasis proyek tentu dirasa semakin besar karena model pembelajaran ini mensyaratkan adanya kolaborasi antar peserta didik dalam membuat produk mereka. Untuk melakukan kolaborasi, mahasiswa perlu melakukan interaksi satu dengan yang lainnya.

Dalam upaya untuk membangun partisipasi aktif mahasiswa, Bapak Satya juga menyediakan ruang refleksi bagi mahasiswa melalui penilaian sejawat. Selama melakukan 
penilaian sejawat, mahasiswa menganalisis proyek yang telah dibuat oleh mahasiswa yang lain. Mahasiswa berinteraksi dengan mahasiswa yang lain baik secara berpasangan maupun secara berkelompok. Mereka berinteraksi melalui diskusi-diskusi online baik dalam platform sinkronus maupun asinkronus. Mereka saling memberi pendapat dan komentar terkait proyek yang mereka analisis. Dengan demikian, akan terbangun pembelajaran yang aktif, partisipatif, dan kolaboratif. Di samping itu, dengan melakukan penilaian sejawat, mereka bisa menemukan kelemahan dan kelebihan yang dimiliki oleh teman mereka. Dengan demikian, secara tidak langsung, mereka bisa meningkatkan pengetahuan dan keterampilan mereka terkait dengan topik-topik yang mereka nilai. Secara empiris, Double, McGrane, dan Hopfenbeck (2020) membuktikan bahwa pembelajaran yang mengimplementasikan penilaian sejawat mampu membantu mahasiswa lebih baik daripada pembelajaran yang tidak mengimplementasikan penilaian sejawat pada mahasiswanya. Selain tujuan untuk membantu siswa dalam mencapai tujuan belajarnya, Sholihah (2021) juga menekankan bahwa selama pembelajaran daring, penting bagi guru/dosen untuk menggunakan penilaian yang otentik untuk mendapatkan gambaran kompetensi siswa/mahasiswa dengan lebih akurat.

Bentuk interaksi penting lainnya yang juga diupayakan oleh Bapak Satya adalah dengan merancang materi pembelajaran yang menarik dan mudah diakses oleh mahasiswa. Menurut Yengin, Karahoca, Karahoca, dan Yucel (2010), perancangan materi pembelajaran yang menarik mampu menarik minat dan mahasiswa untuk mengikuti pembelajaran dengan baik. Salah satu cara yang dilakukan adalah dengan menggunakan video. Penggunaan video telah dipercaya mampu menarik perhatian mahasiswa karena dalam video, mahasiswa tidak hanya disuguhi dengan tulisan-tulisan, tetapi juga visual dan audio (Costley \& Lange, 2017). Terlebih pada pembelajaran mata kuliah sepak takraw yang menekankan pada pada penguasaan keterampilan dasar bermain sepak takraw, sangat penting bagi mahasiswa untuk bisa mendapatkan model yang benar tentang teknik dasar bermain sepak takraw. Mengingat pembelajaran dilakukan secara daring, penggunaan video pembelajaran berupa tutorial teknik dasar bermain sepak takraw benar-benar dibutuhkan untuk memberikan pemodelan kepada mahasiswa. Di samping dikemas dengan menarik, materi pembelajaran juga mudah diakses oleh mahasiswa sehingga mahasiswa bisa mempelajari materi dengan baik.

\section{SIMPULAN}

Berdasarkan hasil penelitian dan pembahasan dapat disimpulkan bahwa Bapak Satya melakukan berbagai strategi untuk melibatkan mahasiswa secara aktif dalam pembelajaran daring. Strategi-strategi tersebut memberi kesempatan kepada mahasiswa untuk berinteraksi kepada dosen, mahasiswa, maupun materi pembelajaran. Strategi-strategi ini penting untuk dilakukan mengingat selama pembelajaran daring berlangsung, mahasiswa memiliki akses yang terbatas untuk melakukan interaksi langsung. Bentuk-bentuk interaksi ini penting untuk menciptakan suasana pembelajaran yang aktif, positif, dan menyenangkan. Dengan atmosfir pembelajaran yang seperti ini, mahasiswa memiliki semangat, minat, dan motivasi untuk mengikuti pembelajaran. Dengan demikian, tujuan pembelajaran akan mampu dicapai dengan baik. Mengingat pentingnya pelibatan mahasiswa dalam pembelajaran daring, dosen sebaiknya mengimplementasikan strategi-strategi pelibatan mahasiswa pada pembelajaran. Meskipun penelitian ini telah memberikan gambaran tentang bentuk-bentuk strategi pelibatan mahasiswa yang bisa dilakukan oleh dosen, penelitian lanjutan terkait sejauh mana strategi-strategi pelibatan mahasiswa ini mampu meningkatkan kompetensi mahasiswa perlu untuk dilakukan.

\section{DAFTAR PUSTAKA}

Al Rasyid, M., \& Khoirunnisa, F. (2011). The effect of project-based learning on collaboration skills of high school students. Jurnal Pendidikan Sains (JPS), 9(1), 113-119. https://doi.org 
10.16714/jps.9.1.1011.113-119.

Avianty, D., and Anantyarta, P. (2010). Efektifitas online learning terhadap keterlibatan siswa dalam pembelajaran tematik (Matematika \& IPA) pada siswa sekolah dasar. Jurnal Pendidikan Matematika Universitas Lampung, 8 (4), 313-14. http://dx.doi.org/10.13960 mtk/v8i1.pp313-314.

Banna, J., Lin, M.G., Stewart, M., and Fialkowski, M. K. (2015). Interaction matters: Strategies to promote engaged learning in an online introductory nutrition course. Journal of Online Learning and Teaching/MERLOT, 11(1), 149-161.

Braun, V., \& Clarke, V. (2006). Using thematic analysis in psychology. Qualitative research in psychology, 3(1), 77-101. https://www.tandfonline.com/doi/abs/10.1191/1478088706 qp063oa.

Braun, V., \& Clarke, V. (2019). Reflecting on reflexive thematic analysis, Qualitative Research in Sport, Exercise and Health, 11:4, 589-597, DOI: 10.1080/1159676X.1019.1618806.

Byrne, D. (2011). A worked example of Braun and Clarke's approach to reflective thematic analysis. Quality \& Quantity. https://doi.org/10.1007/s11135-011-01181-y.

Costley, J., \& Lange, C. H. (2017). Video lectures in e-learning: Effects of viewership and media diversity on learning, satisfaction, engagement, interest, and future behavioral intention. Interactive Technology and Smart Education, 14(3), 169-180. https://doi.org/10.1108/ ITSE-08-1016-0015.

Creswell, J. W. (2007). Qualitative inquiry \& research design. Choosing among five approaches. Second edition. London: Sage Publications Ltd.

Ceswell, J. W. (2009). Research design. Qualitative, quantitative, and mixed methods approaches. California: Sage Publications Inc.

Dixson, M. D. (2010). Creating effective student engagement in online courses: What do students find engaging? Journal of the Scholarship of Teaching and Learning, 10(1), 113. https://www.learntechlib.org/p/54817/.

Dahalan, N., Hassan, H., \& Atan, H.(2011). Student engagement in online learning: Learners attitude toward e-mentoring. Procedia-Social and Behavioral Sciences, 67, 464-75. doi:10.1016/J.SBSPRO.1011.11.351.

Double, K. S., Joshua, A. M., \& Hopfenbeck, T. N. (2010). The impact of peer assessment on academic performance: A meta-analysis of control group studies. Educational Psychological Review, 31, 481-569. https://doi.org/10.1007/s10648-019-09510-3.

Galikyan, I., \& Admiraal, W. (2019). Students' engagement in asynchronous online discussion: The relationship between cognitive presence, learner prominence, and academic performance. Internet and Higher Education, 43, 1-9.https://doi.org/10.1016/j.iheduc. 1019.100691.

Gunuc, S. (2014). The relationships between student engagement and their academic 
achievement. International Journal on New Trends in Education and their Implications, 5(4), 199-114. http://www.ijonte.org/FileUpload/ks63107/File/19..gunuc.pdf.

Khan, A., Egbue, O., Palkie, B., \& Madden, J. (2017). Active learning: Engaging students to maximize learning in an online course. Electronic Journal of E-Learning, 15(1), 107-115. https://eric.ed.gov/?id=EJ1141876.

Lee, J., \& Martin, L. (2017). Investigating students' perceptions of motivating factors of online class discussions. International Review of Research in Open and Distributed Learning: IRRODL, 18(5), 148-71. https://doi.org/10.19173/irrodl.v18i5.1883.

Mali, Y. C. G. (2016). Project-based learning in Indonesian EFL classroom: From theory to practice. Indonesian Journal of English Education, 3 (1), 89-105. http://dx.doi.org/10.15. 408/ijee.v3i1.1651.

Martin, F., \& Bolliger, D. U. (2018). Engagement matters: Student perceptions on the importance of engagement strategies in the online learning environment. Online Learning, 11(1), 105-111. doi:10.14059/olj.v11i1.1091.

Miles, H. M., Huberman,A. M., \& Saldana, J. (2014). Qualitative data analysis. A methods sourcebook. 3rd ed. Los Angeles: Sage.

Mulia, N. A. (2010). Indonesian EFL students' engagement in online language learning platform. RETAIN, 8(1), 154-163.

Pawicara, R., \& Conilie, M. (2010). Analisis pembelajaran daring terhadap kejenuhan belajar mahasiswa tadris biologi IAIN Jember di tengah pandemi Covid-19. ALVEOLI: Jurnal Pendidikan Biologi, 1(1), 19-38. https://doi.org/10.35719/alveoli.v1i1.7.

Reyes, M. R., Brackett, M. A., Rivers, S. E., White, M., \& Salovey, P. (2011). Classroom emotional climate, student engagement, and academic achievement. Journal of Educational Psychology , 104(3), 1-13. https://eric.ed.gov/?id=EJ993886.

Sholihah, M. (2011). Authentic assesment in online learning during the covid 19 pandemic. Edunesia. Jurnal Ilmiah Pendidikan, 1(1), 576-580. https://doi.org/10.51176/edu.v1i1. 167.

Silverman, D. (2015). Interpreting qualitative data. Los Angeles: Sage Publications, Inc.

Stake, R. E. (1995). The art of case study research. California: Sage Publications, Inc.

Stake, R. E. (2010). Qualitative research: Studying how things work. New York: The Guilford Press.

Stake, R. E. (2005). Qualitative case studies. In N. K. Denzin \& Y. S. Lincoln (Eds.), The Sage handbook of qualitative research. Third edition. California: Sage Publications Inc.

Sun, A., \& Chen, X. (2016). Online education and its effective practice: A research review. Journal of Information Technology Education, 15, 157-190. https://doi.org/10.18945/ 3501. 
Triana, D., Anggraito, Y.U., \& Ridlo, S. (2010). Effectiveness environmental change learning tools based on STEM-PjBL towards students' collaboration and communications skills. Journal of Innovative Science Education, 9(3), 144-149. doi 10.15194/JISE.V8I3.35179.

Wahyudi, W., Budiman, D., \& Saepudin, E. (2018). Penerapan model pembelajaran kooperatif tipe TGT dalam pembelajaran permainan bola besar berorientasi sepak takraw untuk meningkatkan kerjasama dan keterampilan bermain. TEGAR: Journal of Teaching Physical Education in Elementary School, 1(1), 1-9. https://doi.org/10.17509/tegar.v1i1. 11731.

Wong, L. (2013). Student engagement with online resources and its impact on learning outcomes. Journal of Information Technology Education: Innovations in Practice, 11, 119146. https://doi.org/10.18945/1819.

Yang, Y. (2011). Engaging students in an online situated language learning environment. Computer Assisted Language Learning, 14(1), 181-198. https://doi.org/10.1080/09588 111.1010.538700.

Yengin, I., Karahoca,D., Karahoca, A., \& Yücel, A. (2010). Roles of teachers in e-learning: How to engage students \& how to get free e-learning and the future. Procedia-Social and Behavioral Sciences, 1(1), 5775-5587. https://doi.org/10.1016/j.sbspro.1010.03.941.

Yin, R. K. (2018). Case study research and applications. 8th ed. London: Sage.

Yunitasari, R, \& Hanifah, U. (2010). Pengaruh pembelajaran daring terhadap minat belajar siswa pada masa covid 19. Edukatif: Jurnal Ilmu Pendidikan, 1(3), 131-143.https://doi. org/10.31004/edukatif.v1i3.141. 